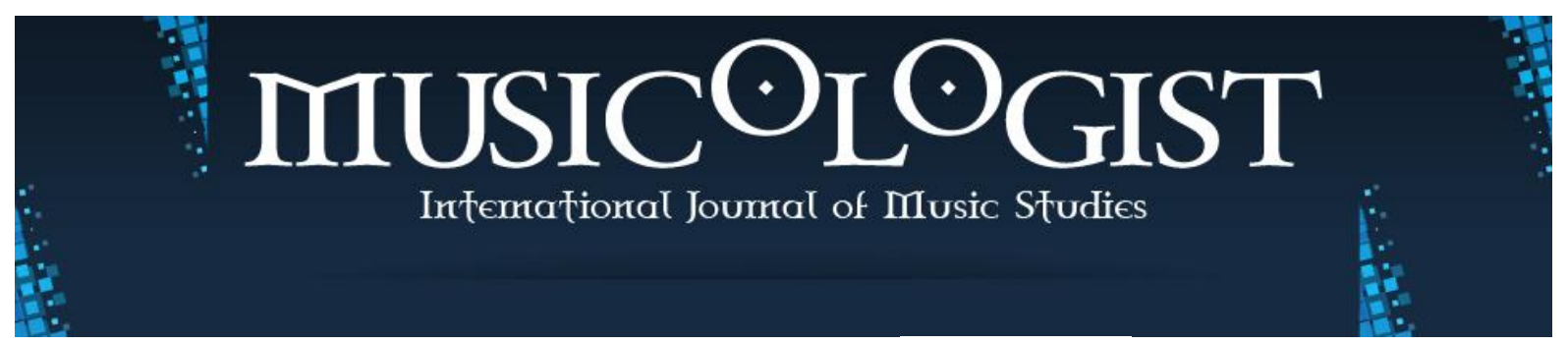

Karadeniz Technical University State Conservatory (C) 2017-2018

Volume 2 Issue 1 June 2018

Research Article

Musicologist 2018. 2 (1): 1-31

DOI: $10.33906 /$ musicologist.439321

\title{
ULRICH MORGENSTERN
}

University of Music and Performing Arts Vienna, Austria

morgenstern@mdw.ac.at

orcid.org/0000-0003-0190-7475

\section{Towards the History of Ideas in Ethnomusicology: Theory and Methods between the Late $18^{\text {th }}$ and the Early 20th Century}

\begin{abstract}
The history of ethnomusicology is the history of ideas and concepts of why and how to deal with expressive practices in social formations which are usually located outside the researcher's primary cultural experience. Ideas in ethnomusicology (comparative musicology, anthropology of music, folk music research, folkloristics) are interlinked with other scholarly disciplines and academic fields. The history of the field is sometimes described as a shift from either a more philologically oriented study of "national" folk music or "armchair anthropology" to a modern anthropological concept expressed in context-oriented, sociological, and performer-centered research, as well as in urban ethnomusicology. However, a great deal of issues frequently associated with English-speaking mainstream ethnomusicology of the last five decades (the "ethnographic turn") appeared in the intellectual folk music discourses as early as the late $18^{\text {th }}$ and the $19^{\text {th }}$ century. In a similar way, the history of comparative musicology as a scholarly concept can be traced back at least to the Age of Enlightenment. This article traces the emergence and early history of motivations, theoretical paradigms and research methods by discussing the following key issues and conceptual oppositions:

Comparative study of musical cultures; Fieldwork experience; Aesthetic appreciation vs. value-free textual analysis; Relativism of expressive cultures: "our" and "their" concepts (emic/etic issues); The paradigm of orality vs. Kunstlieder im Volksmunde; "Living antiquities" vs. the sociology of folklore; Cultural homogeneity vs. performercentered research; Studying songs vs. studying singing; Music in its cultural context-"uses and functions"; Standards of notation and documentation; Rural vs. urban research; 'Cultural purity' vs. intercultural exchange.
\end{abstract}

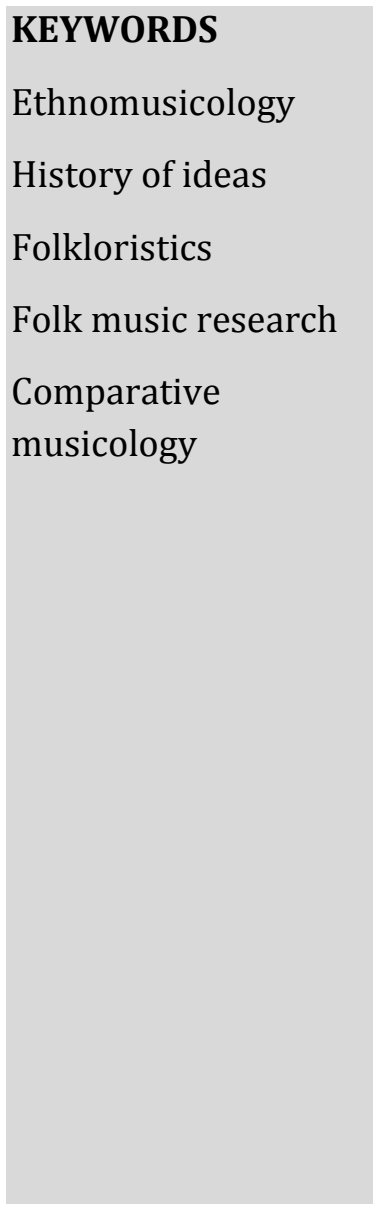


"[...] the history of the field is far more extensive than many had assumed or admitted". Philip V. Bohlman (1991: 148)

\section{Introduction}

The history of ethnomusicology is a history of ideas and concepts of why and how to study expressive practices in social formations mainly (but not exclusively), located outside the researcher's primary cultural experience. New approaches to expressive culture can emerge in various ways and in various intellectual settings. Sometimes they arise as a passing thought, sometimes, however, they are initially established as fundamental concepts of academic scholarship.

Ethnomusicology is interlinked with other scholarly disciplines and academic fields dealing with expressive culture from different (and sometimes not so different) angles, such as comparative musicology, folkloristics, folk music research. These fields of research are defined and configured in most disparate ways. There is no prospect of a generally accepted disciplinary framework, neither in the international academic landscape and nor, perhaps, in any single country.

In the present article, I will give an overview of the emergence and early history of motivations, research methods, and theoretical approaches in the above-mentioned fields. The primary focus will be on key issues and conceptual oppositions emerging either within established academic disciplines or at least in an intellectual environment, characterized by the principles of scholarly thinking, interdisciplinary and international dialogue. Broader social discourses on folk/traditional music, shaped more by cultural and political activism, will be considered to a lesser degree.

The arrangement of the key issues and oppositions approximately follows the chronological order of their origin, in comparative musicology or European folk music research and folkloristics. The first section, which is also the most extensive, covers the topic of comparative study of musical cultures. The second, which deals with the fieldwork experience, is concerned with another fundamental idea in ethnomusicology. The section entitled "Aesthetic appreciation vs. value-free textual analysis" presents different motivations for studying non-European and folk music. The section called 'Relativism of expressive cultures: 'our' and 'their' concepts (emic/etic issues)" explains when ethnomusicology came to deal with different 
sonic systems and their cognitive foundation. "The paradigm of orality vs. Kunstlieder im Volksmunde [Art Songs in the Mouths of the Folk]" traces conceptual oppositions in European folk song research. "Living antiquities' vs. the sociology of folklore" describes the shift from historical to contemporary perspectives. "Cultural homogeneity vs. performer-centered research" traces the growing interest in individual performers and the gradual abandonment of the idea of homogenous traditional cultures. "Studying songs vs. studying singing" discusses a shift from philological repertoire studies to the performance process. "Music in its cultural context-'uses and functions"' explains the early history of the anthropological perspective, while "Standards of notation and documentation" refers to something like "the crisis of representation" in 19th-century European folk music research. "Rural vs. urban research" deals with ethnomusicologists' preferences of different social settings, while “'Cultural purity' vs. intercultural exchange” discusses the significance of chauvinist ideologies of 'the untouched' for academic research, as well as the recognition of cultural transfer.

The time period under consideration extends, roughly speaking, from the early Enlightenment period to the first third of the 20th century. By 'early history', I mean the period before the establishment of the principles both of comparative musicology (Guido Adler) and of post-war ethnomusicology (Alan P. Merriam). I will also include the history of more recent trends and approaches in mainstream ethnomusicology, which are considered to be new. In doing so I will focus less on the well-known periods of the history of the field discussed by Schneider (1976), McLean (2006), Nettl (2010), and others.

\section{Comparative study of musical cultures}

Bruno Nettl in his famous four-part definition of ethnomusicology defines it as "The study of the world's musics from a comparative and relativistic perspective" (Nettl, 2005: 13 , emphasis in the original) ${ }^{1}$. The origins of comparative musicology are generally associated with the systematic use of the phonograph and with new possibilities of precise tone measurement starting in the late $19^{\text {th }}$ century. A history of ideas in ethnomusicology, however, should focus not primarily on the technical

1 The other parts of Nettl's definition include "music in culture" (2005: 12), "fieldwork" (2005: 12) as well as "all musical manifestations of a society" (ibid.). 
possibilities researchers have at hand, but on the intellectual interest towards the musical cultures of the world. The phonograph would never have turned into such an effective tool in the hands of so many ethnographers and musicologists, if the key issues of comparative musicology had not been prepared and developed long before this remarkable technical innovation. Paradoxically, the early history of comparative musicology has been studied by historical musicologists (Rainbow, 1986; Ringer, 1991; Zon, 2006 and 2007; Irving, 2009) more profoundly than by ethnomusicologists, among which Joep Bor (1988), Philip V. Bohlman (1991), and Mervyn McLean (2006) may be called pioneers. Notably, Frank Harrison (1973) covered both disciplines.

The initial research interest for comparative studies was motivated by an universalist, anthropological perspective on music, particularly highly developed during the Age of Enlightenment. Since the late $18^{\text {th }}$ century, comparative methods were also used to identify specific traits of the researcher's "own" musical culture and explore its historical depth.

\section{Anthropological comparativism}

The anthropological approach, i.e. curiosity towards different ways of organizing cultural and social life, seems to be an integral part of European culture from the times of Herodotus. German Historian Egon Flaig, with reference to Jacob Burckhardt, even claims a "far-reaching interest towards foreign cultures" 2 (Flaig, 2007: 253) as one of several exclusive characteristics of European intellectual history.

As Bohlman has shown "a place for non-European music in the European discourse on music" (1991: 132) was provided quite early on. Athanasius Kircher's accounts of non-Western music "would appear to establish him as the first European ethnomusicologist" (1991: 145). Given that ethnomusicology does not necessarily study music outside of Europe, Johannes de Grocheo and his triple model of vernacular (musica vulgaris), composed secular, and ecclesial music also deserves a mention (Stockmann, 1984: 165).

\footnotetext{
2 Titels of non-English books as well as citations from those in the main text are given in the author's translation.
} 
Only four decades after Kircher's Musurgia universalis, sive ars magna consoni et dissoni (1650), German composer and musical writer Wolfgang Caspar Printz in his Historical description of the noble Art of singing and playing (Printz, 1690) offered a systematic framework for nothing less than a well-elaborated anthropology of music. The author draws from biblical stories, taken literarily, from classical and medieval texts, as well as from personal experience in Germany and Italy. Printz explains "the final purpose of music and its different use" (1690: 170-194), distinguishing 14 basic functions of music-making. They include religious, societal, military, psychological, educational, therapeutic, dance, and work-related aspects. According to Printz, the biblical Adam must have invented the art of singing, as he had previously received from God the psychological dispositions and incentives for it (1690: 4). Such theology-based historical speculations (Schneider, 1984: 362f., McLean, 2006: 22), nevertheless, reveal a fundamentally anthropological understanding of music as a precondition of human existence.

In Printz' essay, ethnography is present, yet limited to accidental observations of European practices. The interest in the world's musical cultures increased when systematic accounts by Western explorers, missionaries, traders, and diplomats started to circulate among the social elites. An early comparative study, based essentially on personal observations, is Charles Fonton's posthumously published Essai sur la musique orientale comparée à la musique européenne (1750 cf. Bohlman, 145 f. Jäger, 2011). A wider readership was impressed by Captain James Cook's descriptions of music and dance of the South Pacific. As Erica Lind suggests “Cook's words show a higher degree of anti-ethnocentrism than was common at the time or, indeed, for years after" (Lind, 2008). Lind considers Jean-Jacques Rousseau's Discours sur l'origine de l'inégalité parmi les homes (1754) as one of the writings "directing European focus away from a sense of ethnocentrism to an awareness of the diversity and civility of other cultures" (ibid.). Nevertheless, I think that Cook's ideal of colonial engagement as a collaborative process, to be conducted at eye-level with the natives, is far from Rousseau's essentially anti-Enlightenment stance (Hicks, 2004: 92), idealizing the "noble savage" and seeking to protect him (and her!) from any economic and social progress. 
Three years before Cook's tragic death, English composer and music historian Charles Burney synthesized substantial observations of non-Western music in a General history of music $\left(11776,{ }^{21789}\right)$. This work is largely based on classical texts from Greek antiquity, but also on historical sources on the early civilizations. Burney occasionally includes recent observations of non-European musical practices. His universalist approach derives from his very definition of music:

The love of lengthened tones and modulated sound, different from those of speech, and regulated by a state measure, seems a passion implanted in human nature throughout the globe; for we hear of no people, however wild and savage in other particulars, who have no music of some kind or other, with which we may suppose them to be greatly delighted by their constant use of it (Burney, 1789: 11).

The "science of musical sounds" (1789: 9) essentially depends on the comparative perspective as a precondition for the identification of universal genres, which correspond with most of the basic psychological and societal functions of music so clearly delineated in Printz's essay.

Unsurprisingly, Burney, just like most $18^{\text {th }}$-century writers, was convinced of the global superiority of European music:

Music being the object of a sense common to all mankind, if genius alone could invent and bring it to perfection, why is China, which has been so long civilized, still without great composers and performers? And why are the inhabitants of three-fourths of the globe still content, and even delighted with attempts at such music as Europeans would qualify with no better title than noise and jargon? It cannot be supposed that nature is entirely to blame, and that there is a physical defect in the intellects or organization of all the sons of men (1789: 703).

Burney, however, does not explain differences of sonic systems as an 'innate' inferiority of non-European peoples, but in terms of different listening habits and aesthetic expectations: "the best music of every age and nation is delightful to hearers, whose ideas of excellence are bounded by what they daily hear" (1789: 
704). Seen in this light, it seems premature to claim a "racism of Burney" (Zon, 2007: 5). Unfortunately, Bennett Zon seems to follow Edward Said's popular, yet lopsided concept of 'orientalism' to be discussed later.

According to Joep Bor, Burney did "compile and condense the research of others" (1988: 60), while only François-Joseph Fétis went a step further and "drew his own far-reaching conclusions" (ibid.). Without detracting from Fétis' enormous merits in comparative musicology, we have to admit that Burney conducted comparative research in historical perspective as well. Thus, comparing Greco-Roman sources on the lyre with recent ethnography from Abyssinia, he came to the conclusion that "this instrument seems to have been originally invented in this country, and to have continued in use there ever since" (1789: 25). Contrary to Greek mythology, Burney also, based on recent ethnographies, concludes that "[t]he natives of every quarter of the globe seem to have invented their own flutes (1789: 359).

The fundamental role of organology for early comparative musicology has been recently elaborated by David R. M. Irving. Early modern writings by Europeans "provided crucial building blocks for the development of comparative musicology" (2009: 373), starting with Michael Prätorius. According to Irving,

observations made about non-European musical instruments demonstrate Europeans' curiosity about the musical practices of others (and vice versa), their desire to empathize with other cultures through musical exchange, or their refusal to acknowledge or appreciate foreign musical aesthetics (2009: 374).

A second topic of interest for the early comparative musicologists is the scale systems of the Orient. Their study is as old as the discipline of acoustics (Joseph Sauveur 1653-1716, cf. Ghrab, 2005). Thus, it was definitely not Alexander J. Ellis who "brought into question the superiority of western tempered tuning and led the way to open-minded cross-cultural comparisons of tonal systems", as Helen Myers (1992: 4) claims.

Most authors praised the ancient civilizations for their "arts and sciences" as "advanced to a high pitch of perfection, when the rest of the world remained in a 
state of barbarism and ignorance" (Stafford, 1830: 14). However William C. Stafford was interested not only in treatieses and other historical sources, but also in music of the contemporary Orient. In a chapter devoted to "Modern Egyptian music" he notes that

performers make use of very minute intervals, singing passages of embellishment with a rapidity and volubility, the imitation of which would be found difficult, if not impracticable, to most European singers (1830: 27).

Stafford's History of Music was partly translated into German and Russian and faced several reeditions, but is nearly forgotten in contemporary ethomusicology-or heavily underestimated. At the very least, it is hard to agree with Bennett Zon's opinion that "for Stafford non-Western music is a metaphor for nature. It is unchanging, aesthetically rudimentary, and potentially dangerous" (2006: 190).

Following Stafford, Fétis (since 1837) offered historical explanations for the diverse musical cultures of the world. Of particular interest is Fétis's emphasis of the "oriental" foundations of Western musical culture. While earlier authors believed in the Egyptians' leading role in bringing art and science to Europe, Fétis's studies of India's stringed instruments led him to the famous conclusion that "there is nothing in the West which has not come from the East" (1864 [1856]: 9). Unlike most of his predecessors, Fétis was also highly interested in European folk music. Thus, analysing recent descriptions of chordal accents, typical for Russian instrumental music, he was convinced enough to identify the origin of the Western harmonic system (Morgenstern, 2010: 284).

Another key figure in comparative musicology is German-British musicologist Carl Engel (1818-1882). Bruno Nettl (2010: 43f.) and David Jonathan McCollum (2014: 10f.) have mentioned his open-mindedness and aesthetical appreciation of nonWestern music. However, it is somewhat surprising when Jonathan McCollum claims that "Engel was perhaps the first notable scholar to publish substantial historical works on an array of music traditions outside of the Western canon" (2014: 11). In the same year when Guido Adler established 'comparative musicology', John Frederick Rowbotham, a Scottish theologian and conservatory-trained musicologist, 
in his monumental History of Music offered an evolutionist model of music history according to organological taxonomies:

the order of the 3 Stages in the development of Prehistoric Music, the Drum Stage, the Pipe Stage, and the Lyre Stage, which, it seems to me, are to the Musician what the Theological, Metaphysical, and Positive Stages are to the Comtist, or the Stone, Bronze, and Iron Ages to the archaeologist (1885: $\mathrm{xx}$ ).

According to his obviously speculative model (Schneider, 1984: 368), "the history of savage races is a history of arrested developments [...] The dawn of history in the hoary civilizations of Egypt and Assyria, which seems twilight to us, is radiance compared with their gloom." (1885: 1)

To the contemporary reader this may appear to be entirely racist, however Rowbotham, in his empathic way, concedes an "aesthetic instinct in the harsh practical rounds of their every day life" (ibid.), as

[i]n their often ineffectual struggles to realise the beautiful and the good we may see enacted over again the struggles of our common ancestorMan. And we cannot but sympathise with them in their naïve efforts to realise these things and more especially the first (ibid.)

In his second book, 'The music of the elder civilizations', Rowbotham distinguishes between 'lyre races' (Egyptians, Assyrians, Hebrews) and 'pipe races' (China, IndoChina or Mongoloids). His through hierarchization of 'savage', 'barbarous' and 'civilized' peoples bears the hallmarks of $18^{\text {th }}$ - and $19^{\text {th }}$-century comparative musicology-regardless of the author's sympathetic attitude towards the general creative potential of any human being.

We can conclude that comparative musicology from its very beginning in the Age of Enlightenment was fundamentally anthropological, still with ambivalent attitudes to non-Western musics:

The convergence of different societies around the world as a result of sustained contact through trade, diplomacy, or colonialism in the early 
modern period meant that hierarchies of cultural and religious symbolism had to be recast in the light of intercultural comparisons, but in some cases they were unceremoniously supressed by a hegemonic imperial power (Irving, 2009: 383).

To be sure, not any convergence in the musical cultures of the world can be explained by intercultural exchange. Whatever the case may be, Irving's study of early modern comparative musicology could be a starting point for ethnomusicologists to overcome well-established stereotypes of postcolonial theory. In the light of European music anthropology Edward Said's objection that "every European, in what he could say about the Orient, was consequently a racist, an imperialist, and almost totally ethnocentric" (1978: 204) appears more than illinformed.

Comparative approaches are not foreign to European folk music research either. Thus, Johann Gottfried Herder observed "war-cry and lament, battle-song and funeral dirge, historical paeans on their forefathers" ([1773] (Nisbet, 1985: 157) among native Americans as well as in what he considered to be ancient Scottish poetry (cf. Morgenstern, 2015). While focusing in his comparative research on textual and functional aspects of the Volkslied, Herder didn't play a considerable role in musicological discourse of his time. As Matthew Gelbart puts it:

Yet Herder's anthropological and artistic claims in his writing on Volkslieder did not translate directly into musical terms; so when it came to formulating the technical side of folk music, Burney played a larger role than Herder even in Germany (Gelbart, 2007: 137).

In a similar way, Alexander Nebrig (2014: 320f.) has pointed to Herder's limited involvement with music. The actual founder of folk music research in Germany was not Herder, but Friedrich David Gräter (1768-1830, cf. Mueller, 2012; Morgenstern, 2015) whose conceptual innovations will be shown below.

A universalist approach is clearly expressed in early British folkloristics, which was developed as a realist counter-model to the historically oriented mythological school of the Grimm brothers. When William Thoms replaced "popular antiquities by folk- 
lore" (Boyer, 1997) he did so as he hoped for a "discovery of some unvarying principles of the human mind" (Thoms, 1848: xii-xiii).

\section{Comparativism in a national context (and for national purposes)}

Comparative musicology in some cases focuses on ethnically and/or linguistically related groups in order to identify common traits of textual and musical means of expression. Gräter was one of the first who encouraged, in analogy to linguistics, "to compare our folk songs with the folk songs of related peoples" (1794: 208). Ludwig Uhland preferred to draw comparisons between German folksongs and not English or Scandinavian songs, but with those of the Netherlands, motivating his preference with closer linguistic relation (1845: vi f.) Such research could make or not make a claim for the legitimization of the nation or of the dominance of a particular group within an ethnically heterogeneous country.

Strangely enough, a strong chauvinist bias can be observed in the first conceptual introduction to comparative musicology in Germany. For the nearly (and luckily) forgotten Oskar Fleischer, comparative musicology was subordinated to his obsession with Germanic antiquity (Morgenstern, 2015). In the first half of the $20^{\text {th }}$ century ethnomusicologists continued comparative research on musics of ethnically related groups. Needless to say that Béla Bartók, as well as Zoltán Kodály in Hungary, Łucjan Kamieński in Poland, and Klyment Kvitka in the Ukraine represent a scholarly level and an intellectual environment far from Fleischer's ideologydriven speculations.

Be it historical reconstruction, an empathy for the diversity of expression, or the quest for particular national or ethnic characteristics - the comparative approach to the musics of the world is fundamental to European musical thought.

\section{Fieldwork experience}

Sociological approaches in ethnomusicology and folkloristics naturally emerged whenever researchers shifted the perspectives from written sources to personal experience with living expressive culture. Fieldwork is the conditio sine qua non for any ethnomusicologist and is included in the definition of the field (Nettl, 2015: 16f.). 
For Herder, personal experience with living traditions was not only the starting point for his interest in folk songs. He even developed a clear concept of how to do fieldwork:

There I wanted to hear a living performance of a living people's songs, see them in all their effectiveness, see the places that are so alive in all their poems, study in their customs the remains of that ancient world, become for a while an ancient Caledonian myself ([1773] Nisbet, 1985: 157).

Herder could not make his dream true. Yet the fundamental concept of ethnomusicology—context-oriented fieldwork, and even the strategy of temporal "'going native"-was born. One of the first to practice the former was Gräter. Convinced that folk songs should be studied not only from written sources but from actual performance, he describes typical research situations when he listened, secretly and unrecognized, to the intimate singing of shepherds, reapers and village girls (1794: 248f.).

Fieldwork not only made empirical data accessible to ethnomusicologists, it also helped them develop theoretical concepts. This is all the more important to folklorists and folk music scholars who, as a rule, were able to communicate directly with their research partners in the field and to explore their understanding of expressive culture.

\section{Aesthetic priorities vs. value-free textual analysis}

Following Alan P. Merriam, Mervyn McLean makes a case for a strictly academic profile of ethnomusicology: "As a discipline ethnomusicology is more concerned with science than with art. Appreciation of exotic forms of music, their intrinsic worth, and even the desire to promote them may play a small part, but is not essential" (2006:21).

This may be true for ethnomusicology as a scholarly discipline, but McLean does not necessarily reflect the personal motivations and agendas of ethnomusicologists themselves. Some early comparative musicologists (Fonton, Guillaume-André Villoteau, possibly also Augustus Willard, cf. Zon 2007 253f.) learned to play non- 
European instruments under the tutelage of native teachers. Others, however (Burney, Forkel, Raphael Georg Kiesewetter) despite viewing foreign musical systems as legitimate research objects, were less empathetic to their aesthetic qualities. Both approaches can be found in European folksong scholarship.

Herder and his followers established folk songs as a positive model (albeit not a normative criterium) for the development of national literatures. Since the late $18^{\text {th }}$ century up to the present countless poets, composers, pedagogues, revival musicians, or simply connoisseurs, celebrated folk song texts and vernacular music for their expressive qualities, as did Gräter. However, he spent a lot of effort on the description and explanation of song texts he considered to be of low aesthetical but high historical value. Sceptical about "lyrical flower-picking" (1794: 208), he implicitly established a contraposition to Herder's aesthetics (cf. Morgenstern, 2015).

Gräter's essay anticipates the spirit of the post-romanticist 'realist turn' in mid-19th century folk music research. One of its early representatives was Ludwig Uhland. His collection of texts of German folk songs "is neither a moral or aesthetic sample collection but a contribution to the history of German folk live." (1845: viii)

Of particular interest is the non-romantic folk song concept of Russian writer and revolutionary democrat Nikolai Dobroliubov. Contrary to what he called "gastronomic science" (1962 [1857]: 237) he called for a study of folk songs within a sociological perspective with political consequences: "We are to know the inner life of the folk, if we want to do anything for their enlightenment and refinement [...] we have to begin with the widest possible knowledge of their ideas and their stage of development" (ibid.: 233f.) ${ }^{3}$.

In Anglo-American folk song research, conflicts between romanticist idealism and realism emerged later, as James Porter (1991) has shown in detail. The key figures, Cecil Sharp (1859-1924) and Percy Grainger (1882-1961), both stood for a transfer of folk music to modern life: the former as a pedagogue, whose aim was 'to return' idealized folk songs to the people, as a positive model for social life, "a symbol of

${ }^{3}$ Some more about Dobroliubov's concept I will present in my forthcoming publication (s. footnote 4). 
better things to come" (Nettl, 2015: 346), the latter as a folklorist with high standards for documentation and transcription, and as a composer, whose valorisation of folk music was primarily a matter of aesthetics.

It seems that from the times of Grainger and Bartók up to the 1980s only two ways of involvement with folk music, two role models, enjoyed a high reputation in the intellectual elites of Europe: the dispassionate academic researcher and the advanced composer. It was only in the Golden Age of European folk music revival when academia opened the door for new ways of combining scholarship and artistic initiatives.

\section{Relativism of expressive cultures: 'our' and 'their' concepts (emic/etic issues)}

Bruno Nettl emphasized ethnomusicology's "comparative and relativistic perspective" (Nettl, 2005: 13, see above). In the third edition of The Study of Ethnmusicology, however he changed 'relativistic' to 'egalitarian' (2015: 16). Personally, I prefer his older definition. It is doubtful that most people seriously involved in art would agree that "in terms of quality we regard all musics as fundamentally equal" (ibid.). Given that ethnomusicologists concentrate on "music that is accepted by an entire society as its own" (Nettl, 2005: 13) this cannot be any music. In other words, Nettl's prior definition is more appropriate in terms of avoiding the postmodernist concept of ethnomusicology McLean has caustically characterized as "the application of scholarship of any kind to music of any kind" (2006: 13).

Today it is almost common sense that ethnomusicologists study a musical system or a set of local practices "in its own terms" (Hood, 1960). Nevertheless, it was argued that the emic perspective may conflict with the comparative approach (Schneider, 1997: 20-23) and that a radical cultural relativism is hardly compatible with the idea of human rights (ibid.: 30f., see also: Flaig, 2007). Less problematic is a relativistic approach to the study of expressive cultures.

The acceptance of different aesthetic concepts can be traced back to at least the $18^{\text {th }}$ century. An early attempt for a systematic understanding not only of different tonal systems, but also of different concepts of musical thinking is Fonton's abovementioned essay on Turkic music (1750). Ralf Martin Jäger sees this as a general 
shift "towards an emic-intracultural perspective that seeks to make accessible foreign music according to the principles of its own theory, considering its own terminology" (2011: 479).

Cultural relativism is fundamental to Herder's anticolonial impetus (Noyes, 2015) and to his readiness to regard "culture" not a privilege of "civilization", but an essential part of any social formation. Izaly Zemtsovsky (2012) informs us that an understanding of different ways of hearing in peasant culture and in the social elites drove mid-19th century Russian folk music research to the study of emic concepts as one of its main tasks. A clear distinction between insiders and outsiders of the folk music culture within a single country was, at least until recently, typical, in scholarly as well as revivalist discourses in most parts of Europe.

\section{The paradigm of orality vs. Kunstlieder im Volksmunde}

A particular field of conflicts between idealism and realism is the lively debate on the significance of oral transmission on the one hand and the role of writers and composers on the other. From Herder and Gräter and beyond Roman Jacobson and Pëtr Bogatyrëv, generations of folklorists have admired, and theorized on, how rather complex repertoires could be transmitted without the help of medial fixation. Most clearly the 'paradigm of orality' was formulated in Gräter's definition of the Volkslied: "actual folk songs" are "songs, originally sung by the people, commonly known and preserved solely through oral transmission and folk singing" (1794: 208).

Naturally, oral transmission has consequences for the structure of a repertoire, as well as for the decisive role in its social acceptance. All this is crucial for the development of academic folkloristics and its emancipation from literary studies. On the other hand, oral transmission does not necessarily imply an origin in illiterate settings. Since the late $19^{\text {th }}$ century, folklorists have been discussing the role of written literature for Russian epics, English ballads and many other genres. Discourses on the provenance of vernacular songs are one of the battlefields in which adherences to the realist turn challenge the romanticist folksong concept. That's why debates on orality so often take a heightened note. Wilhelm Tappert (1830-1907) presented the results of his investigation, which proved many German 
vernacular melodies to be the work of domestic or foreign composers, in a rather sarcastic way (Nettl, 2015; Morgenstern, 2015). In a similarly categorical tone, a leading US-American folklorist William Wells Newell (1839-1907) discussed the origin not only of children's games but also of other folklore genres:

It is altogether a mistake to suppose that these games (or, indeed, popular lore of any description) originated with peasants, or describe the life of peasants. The tradition, on the contrary, invariably came from above, from the intelligent class (Newell, 1884: 7).

In German folksong research, generally, John Meier's Kunstlieder im Volksmunde (1906) is presented as the starting point for the Rezeptionstheorie. However, international history of folkloristics shows that he was neither the only and nor the first one to make a case for the significance of written origins of many vernacular songs.

Increasingly folklorists challenged the paradigm of orality, and not only in terms of the origins of certain repertoires in bourgeois culture. Literacy was more and more discussed as a cultural technique continuously used by the members of the communities under study. Written texts are crucial not only for the circulation of song and melodies in traditional communities, but also for instrumental music. In $19^{\text {th }}$-century Austria and Germany many rural musicians, notably fiddlers, were able to read notes, and collected numerous manuscripts. It is obvious that the role of what is called written folklore (Alan Dundes), i.e. poetry albums, graffiti, etc, increased with the general progress of education.

In mainstream ethnomusicology, until recently, orality/aurality has been taken for granted as defining the basic field of investigation: "In general, music in oral tradition and living musical systems are the realms that have most appealed to ethnomusicologists" (Myers, 1992: 3). However, since their increasing interest in non-Western (media-based) popular music, such positions were being continuously, and tacitly, eroded. Nettl appeals to the personal experience of his reader, concluding that "[m]usic is transmitted to almost every individual in many ways" (2015: 295). 


\section{'Living antiquities' vs. the sociology of folklore}

A historical perspective is of high priority both in comparative musicology and in European folk music research and folkloristics. The development of specific genres has been widely discussed, several methods of reconstruction were offered, and, in many cases, speculative approaches developed and debunked (Schneider, 1976). In the $19^{\text {th }}$ century, romanticist folklore discourses were inspired by the imagination of Ancient Germans, Celts, Slavs, etc. Probably, the most reliable historical studies were offered by historical organology, due to a more favourable source basis.

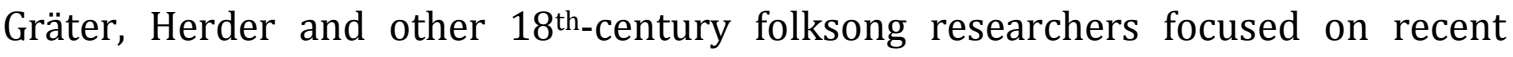
musical practices, which were largely understood as 'living antiquities'. In Herder's concept, the antiquity of the folk songs he preferred necessarily guaranteed their aesthetic value. The preference of older genres is typical for the first half of the $19^{\text {th }}$ century. As fieldwork was intensified in the following period, contemporary repertoires came into view as a research object in its own right-be it to distinguish (privileged) old genres from new ones, or due to an unbiased, quasi-sociological, research interest in modern life. This was the way "From Antiquities To Folklore" (Boyer, 1997).

In a systematic way, sociological methods were developed in the first third of the $20^{\text {th }}$ century by Klyment Kvitka in the Ukraine, Evgenii Gippius in Russia, and Constantin Brăiloiu (1970 [1931]) in Romania. Therefore, the widespread scepticism of some US-American folklorists towards the 'antiquarian' European folklore studies with their "historical bias" (Dundes, 1966: 241) is short-handed (see also Kirshenblatt-Gimblett, 1983: 177).

\section{Cultural homogeneity vs. performer-centered research}

The growing understanding for the diversity of the world's musical cultures initially carried in itself a tendency to consider the latter to be a closed system. The nation or the ethnic group as a collective subject plays a big part both in comparative musicology and in folk music research. This can be explained, in some cases, by the cultural distance of European scholars from non-European musics, and by the limited range of sources, which sometimes led them to premature generalizations. In folk music discourse, collectivist ideologies sometimes promoted the belief in 
homogenous national cultures, be it as an imagination of the past or as an ideological claim to the future (Morgenstern, 2011: 251-254). The idea of a unified folk culture is reflected in stereotypical phrases like 'among the people', formerly widespread in European folk music studies.

Nevertheless, even in Herder's writings the 'national spirit' (Nationalgeist) is always present in balance with the creative individual. Again, intensified fieldwork led folk music researchers to a more differentiated and realistic picture. This considers not only the social diversification of traditional societies, but also a closer look at the personality of the performer.

The performer-centered paradigm in folkloristics and ethnomusicology came about in the last third of the $19^{\text {th }}$ century. ${ }^{4}$ At first only exceptional performers were the focus of field research, but later 'average' singers and musicians came under consideration as well. The fields in which 'ethnomusicology of the individual' has been most developed are: Russian epic studies (starting with Pavel Rybnikov, 1864), Irish and Anglo-American ballad research (Percy Grainger, 1915), tale studies (Mark Azadovskii, 1925), US-American (Francis O’Neill 1913) and European (Felix Hoerburger, 1966) ethnoorganology, US-American "applied folklore" (Benjamin A. Botkin 1954), as well as and Hungarian and Romanian ethnochoreology (György Martin, Anca Giurchescu). Alongside with strategies of advocacy and 'public folklore', performer-centered research was always close to sociological trends in folkloristics and ethnomusicology. Theories on individual creativity were developed in late $19^{\text {th }}$ century and later by Russian and US-American folklorists.

In mainstream ethnomusicology, performer-centered research was, until recently, less developed. Alan P. Merriam devoted two chapters of his Anthropology of Music to the social behaviour and the learning process of the musican (1964: 123-184). However, studies of individual performers, in any considerable number, only appeared in the last two decades.

\footnotetext{
${ }^{4}$ S. my paper The Individual Paradigm in Ethnomusicology and Folkloristics: 150 Years of History, held September 192015 at the 31 ${ }^{\text {st }}$ European Seminar in Ethnomusicology Making a Difference: Music, Dance, and the Individual. As a publication is in preparation I will only briefly touch the most important trends in performer-centered research, and recommend to the reader Colin Quigley's exceptionally well-informed Bibliographical essay $(1995,251-$ 263).
} 


\section{Studying songs vs. studying singing}

In modern ethnomusicology, as well as in German musikalische Volkskunde in the tradition of Ernst Klusen, it is frequently claimed that a shift from studying songs to studying the process of singing is a comparatively recent trend. However, dealing with genres from oral transmission, folklorists have been long aware of the variability of song texts not only in different regional and local frameworks but also within the individual repertoire of a single performer. The acknowledgement of the processual nature of folklore not only helped $19^{\text {th }}$-century British and Russian folklorists emancipate themselves from philological theories developed for the study of written literature, it also sharpened the researchers' attention to inner and outer impulses during the process of performance.

Performance can be studied as social interaction within a vocal and/or instrumental ensemble, between musicians/singers and dancers. Russian ethnomusicologists such as Evgeniia Linëva (Eugenie Lineff, 1854-1919), composer and musical thinker Boris Asaf'ev, as well as his disciples Zinaida Eval'd (1894-1942) and Evgenii Gippius (1903-1985) focused not only on large social formation, but were highly attentive to the process of singing in small groups, as well as to the interaction between performers and possible audiences.

In ethnomusicology, Bruno Nettl and Thomas Turino have significantly contributed to the study of performance. Particularly inspiring is Henry Glassie's understanding of tradition as a creative process, as "tradition in performance" (1995: 401-405), as "continuous process situated in the nothingness of the present, linking the vanished with the unknown" (ibid.). Folklorists' approach to "tradition", could help ethnomusicologists break the deadlock of Eric Hobsbawm's hopelessly overstated concept of tradition, which has very limited value for the study of vernacular expressive cultures. Without any doubt a reconsideration of tradition, and therefore of "traditional music" is a key issue for modern ethnomusicology (cf. Richter ed. 2012).

\section{Music in its cultural context-'uses and functions'}

The study of the musics of the world in their cultural context is crucial to many representatives of comparative musicology, beginning with Printz and going beyond 
Curt Sachs. Again, organology played a leading role: “[c]omparative organology proved to early modern scholars that musical instruments served a diverse range of functions throughout the world, and that their use was often governed by religious tenets" (Irving, 2009: 383).

It is questionable whether it would be possible for any open-minded intellectual involved in foreign or folk music through fieldwork, to fully ignore its social contexts. At least, context-oriented research came about when scholars were ready to study non-European music in the field with the help of native specialists or when they did 'ethnomusicology at home'.

Cultural context is discussed in European folk music research most of all with regard to the diverse social and aesthetic functions. This was a corner stone in Gräter's musical ethnography (Morgenstern, 2015), and it is only natural wherever scholars focus not only on written sources, but also on their personal observations. Thus, 'music in culture' to a higher or lower degree, is initially a part of any fieldworkbased musicology. Without functional analysis any concepts of musical genres would be obsolete.

In European folk song and folk music research, at least since the mid-19th century, the traditional functions of the songs are noted in most of the academic song collections. This leads us directly to editorial standards for the publication of folk songs.

\section{Standards of notation and documentation}

As Bohlman points out "[e]thnomusicology has always relied on a variety of media and techniques to represent other musics and musical cultures" (1991: 139). The proper way of using these representational techniques has been critically discussed since the late $18^{\text {th }}$ century. This initially concerned the accuracy of folk song texts to be published. Herder mocked "the follies of our song improvement" (1773: 69). In his Deutscher Liederhort Ludwig Erk expressed his "foremost aim to present the melodies securely and unadulterated, not less the words, particularly from oral tradition" (1856: vi). Similarily, Vissarion Belinskii demanded to write down Russian folk songs and tales "as faithfully as possible after the dictate of the folk and not to renew and to rework them" (1835: 144). Throughout nearly the entirety of the $19^{\text {th }}$ 
century, folklorists decried the widespread practice of publishing folk songs with piano accompaniment.

The claims of accurate presentation of songs from oral tradition went hand in hand with the development of heightened standards of documentation of time, place and, eventually, also circumstances of performance and the names of the singers. The emotional tone of these debates on proper representation can be understood as a case for the intrinsic value of vernacular music, and against imposing bourgeoise standards on the tradition under study. It is impossible not to notice parallels to early postcolonial approaches in ethnomusicology.

\section{Rural vs. urban research}

It is often said that European folk music research is directed by an idealisation of the village, largely ignoring urban styles and repertoires. This may be true of certain trends in popular folk music discourse, and to some extent, of $19^{\text {th }}$ century academic agendas. However, Jacob von Stählin who invented the term "Volks-Musik" (1770: 65) in his Russian ethnography included "the common Russian national music of the common people in villages, small settlements and cities" (1770: 61). Gräter studied song and dance practice of his native city Schwäbisch Hall in great depth, comparing rural and urban styles and repertoires.

Nevertheless, tendencies of philoruralism cannot be overseen in the history of European folk music research (Bennett, 1993). In the romantic period, but also in the period after the realist turn, a general prioritization of rural genres may be explained by the fact that locally diversified traditional repertoires in rural areas were more resistant to transformation processes-and were, therefore, an attractive subject for historically oriented research (the 'living-antiquities' approach). In 19 th $^{\text {th }}$ century, however, an aesthetic and increasingly ideological antiurbanism affected large parts of the folk music discourse. At the turn to the $20^{\text {th }}$ century anti-urbanism happened to merge in an ideological amalgam with antimodernism, sanitarianism (life reform), antisemitism and reactionary anticapitalism (Morgenstern, 2017: 23, 31f.). It goes without saying, that most innovative directions of European academic folk music research of that time (in Russia, Finland, Great Britain) were far from being involved in these discourses. 
Notably, folklore studies in the United States from the very beginning had a strong focus on expressive cultures of the urban area. Nevertheless, Adelaida Reyes, whose merits in this field are without question, states that "[i]n the 1970ies, urban ethnomusicology was a new term" (Reyes, 2007a: 9). This is true-but only for the term itself, and not for the study of vernacular music in urban areas. The "Bibliography of Urban Folklore" (Collins, 1975) counts 58 titles related to music and published between 1892 and 1969, among them articles by Charles Seeger, Willard Rhodes, Alan P. Merriam, and Bruno Nettl. None of them are mentioned in Reyes' “Urban Ethnomusicology Revisited” (2007b).

Very often urban folklore goes hand in hand with politically inspired activism of "applied folklore" (more precisely, "applied folkloristics"), initiated by Benjamin Botkin in 1954 and institutionalized in the early 1970s. This early history of "applied ethnomusicology" (initially interlinked with minority studies), until recently, was hardly known in mainstream ethnomusicology. ${ }^{5} \mathrm{~A}$ more critical stance towards such continuous reinventions was expressed, not surprisingly, in theoretical folkloristics:

Indeed, the persistence of the phenomena we like to study does not guarantee the survival of our disciplinary subject. Every time anthropology, ethnomusicology, and cultural studies take up "our" topics, they remind us of this axiom. Herein lies the crisis. (KirshenblattGimblett, 1998: 302).

\section{'Cultural purity' vs. intercultural exchange}

Ideologies of cultural purity have a long history in folk music discourse. They can be found in Herder's, and sometimes in Gräter's writings, yet Herder as a universalist played a most contradictory role. But above all, and in the most aggressive way, these ideologies manifest themselves in non-academic agendas of folklore enthusiasts, cultural activists, and nationalist composers. Only a few internationally known folk song researchers, notably Vuk Karadžić, Franjo Kuhač, and (to some degree) Zoltán Kodály, put a strong emphasis on cultural exclusiveness in the sense that Svanibor Pettan has described as the "purist paradigm in folk music research" (2001: 130). In general, however, it seems that Pettan's lucid analysis of a nationalist

\footnotetext{
${ }^{5}$ See briefly my paper mentioned in footnote 4 .
} 
folk music ideology is less applicable to academic scholarship than it is to popular, and without a doubt, persistent discourses, and to cultural activism.

Interestingly, Herder's younger contemporary Gräter was skeptical to the idea of a Nationalgeist: "I don't know how one is be able to define sufficiently the national spirit in which German folk songs differ from the English, Scottish, Danish, and others." (1794: 207)

According to Gräter, the general character of "all good folk songs" (ibid.) is easier to identify than its national belonging. In a similar way, Walter Wiora argued that Chopin and Grieg used musical elements, considered to be national, which should be better explained as common features of early European folk music styles (Wiora, 1957: 163).

Nearly all important European folklorists and folk music researchers have always been highly attentive, and sometimes also sympathetic, to the processes of intercultural exchange. Particular contributions to this field belong to Friedrich Salomon Krauss, Ingeborg Weber-Kellermann, to nearly all notable ethnoorganologists, and also to Béla Bartók, who categorically refuted the idea of "Race Purity in Music" (1944).

\section{Conclusion}

Even a short overview of the study of non-European music, as well as of European folk music since the Age of Enlightenment shows that the intellectual history of ethnomusicology is based on concepts, which could emerge independently from each other in different times and in different places. Historical, anthropological and comparative perspectives have been established, and largely discussed, long before Guido Adler declared comparative musicology as a sub-discipline of musicology.

Dániel Lipták recently suggested that the organological legacy of Hungarian ethnomusicologist Oszkár Dincsér (1911-1977) "includes almost every topic and approach set out by Merriam twenty years later" (2017: 36f.). I would go even further and state that except certain postmodernist ideas (and doctrines) there is not a single influential concept in theory and method of modern ethnomusicology 
that has not been developed much earlier in European and American folk music research and academic folkloristics, or in early comparative musicology.

After all, the history of ideas in ethnomusicology shows that the concept of 'Orientalism', fashionable in the ivory towers of the West, is not applicable to the position of our discipline's leading representatives. Early comparative musicology in its historical narrative doesn't impose a hierarchy between "the West and the rest" but distinguishes "barbarism" from "civilization", which always encompasses Europe and the Orient. That's why we have good reason to think about a necessary 'depostcolonialisazion of ethnomusicology'6.

For the future of ethnomusicology it is of paramount importance that we come to a deeper understanding of our discipline's intellectual history. Recognition of the innovations in theory and methodology, launched by academic folkloristics and folk music researchers, as well as of their past critical debates, is pivotal to ethnomusicology's scholarly location and to its future agendas. Albeit, claims for a place of ethnomusicology in a clearly defined disciplinary framework appear to be utopian, history of ideas in our field can help ethnomusicologists come to fairer and more harmonious interrelations with our neighbouring disciplines and other intellectual projects in the study of expressive culture.

\section{REFERENCES}

Bartók, Béla. (1944) “Race Purity in Music.” Horizon 10: 403-406.

Belinskii, Vissarion. (1835). [Review of the book, Konek-gorbunok. Russkaia skazka by Pëtr Ershov]. Molva (IX, 9).

Bennett, Gillian. (1993). "Folklore Studies and the English Rural Myth." Rural History 4(1): 77-91.

Bohlman, Phillip V. (1991) "Representation and Cultural Critique in the History of Ethnomusicology" Comparative Musicology and Anthropology of Music. Eds. Nettl, Bruno and Bohlman, Phillip: 131-51. Chicago: The University of Chicago Press.

\footnotetext{
${ }^{6}$ An essay on this topic will be published in Musicologica Austriaca (www.musau.org).
} 
Bor, Joep. (1988). “The Rise of Ethnomusicology: Sources on Indian Music c.1780c.1890." Yearbook for Traditional Music 20: 51-73.

Boyer, Troy. (1997) "The Forsaken Founder. Wiliam John Thoms - From Antiquies to Folklore" The Folklore Historian. 14: 55-61.

Brăiloiu, Constantin. (1970 [1931]) "Outline of a method of musical folklore." Ethnomusicology. 14(3): 389-417.

Burney, Charles. (1789) A General History of Music, From The Earliest Ages to the Present Period. To Which is Prefixed, a Dissertation on the Music of the Ancients. Volume the First. (2nd ed.), London: Robson and Clark [Original work published 1776].

Collins, Camilla. (1975). “Bibliography of Urban Folklore.” Folklore Forum. 8(2, 3): 57-125.

Dobroliubov, Nikolai (1962 [1857]). Dobroliubov, N. A. Sobranie sochinenii, Bursov, B. I. et al. (Ed.) vol. 3. Moscow: Izd-vo AN SSSR.

Dundes, Alan. (1966). “The American Concept of Folklore.” Journal of the Folklore Institute 3(3): 226-49.

Erk, Ludwig. (1856). Deutscher Liederhort. Auswahl der vorzüglicheren deutschen Volkslieder, nach Wort und Weise aus der Vorzeit und Gegenwart gesammelt und erläutert. (German Song Treasury. Selection of Excellent German Folk Songs, in Text and Melody collected from Ancient Times and the Present and Explained) Berlin: Th. Chr. Fr. Enslin.

Fétis, François Joseph. (1864). Notice of Anthony Stradivari, The Celebrated Violinmaker, Known by the Name of Stradivarius: Preceded by Historical and Critical Researches on the Origin and Transformations of Bow Instruments; and Followed by a Theoretical Analysis of the Bow, and Remarks on Francis Tourte, the Author of its Final Improvements. (Bishop, John Trans.) London: Robert Cocks \& Co. [Original work published 1856]. 
Flaig, Egon. (2007). "Levi-Strauss im anti-universalistischen Gefängnis. Zum Verenden des Multikulturalismus." (Levi-Strauss in the Anti-universalist Prison. Towards the Perishing of Multiculturalism) Zeitschrift für Kulturphilosophie. 1(2): 325-353.

Gelbart, Matthew. (2007). The Invention of Folk Music and Art Music: Emerging Categories from Ossian to Wagner. Cambridge: CUP.

Ghrab, Anas. (2005). "The Western Study of Intervals in 'Arabic Music' from the Eighteenth Century to the Cairo Congress". The World of Music. 47(3): 55-79.

Glassie, Henry. (1995). “Tradition.” The Journal of American Folklore, 108(430): 395412.

Harrison, Frank. (1973). Time, Place and Music: An Anthology of Ethnomusicological Observation c. 1550 to c. 1800 . Amsterdam: Frits Knuf.

Herder, Johann Gottfried. (1773). "Auszug aus einem Briefwechsel über Ossian und die Lieder alter Völker." (Extract from Correspondence on Ossian and the Songs of Ancient Peoples) In Von Deutscher Art und Kunst. Einige fliegende Blätter. Hamburg: Bey Bode, [engl. transl. s. Nisbet 1985].

Hicks, Stephen Ronald Craig. (2004). Explaining Postmodernism: Skepticism and Socialism from Rousseau to Foucault Cover. Tempe, Ariz: Scholargy Publishing.

Irving, David R. M. (2009). “Comparative Organography in Early Modern Empires” Music \& Letters. 90(3): 372-398.

Jonathan McCollum, David G. Hebert. (2014). Theory and Method in Historical Ethnomusicology. New York and London: Lexington Books.

Jäger, Ralf Martin. (2011). “Der Beginn der wissenschaftlichen Erforschung osmanischer Kunstmusik im Europa der Aufklärung" (The Beginning of Scientific Research on Osmanic Art Music in Enlightenment Europe) Europa und die Türkei im 18. Jahrhundert. ed. Barbara Schmidt-Haberkamp: pp. 473-488. Göttingen: V\&R Unipress. 
Kirshenblatt-Gimblett, Barbara. (1983). "The Future of Folklore Studies in America: The Urban Frontier." Folklore Forum. 16(2): 175-234.

Kirshenblatt-Gimblett, Barbara. (1998) "Folklore's Crisis" Journal of American Folklore. 111(441): 281-327.

Lind, Erica. (2008). "Captain Cook as Ethnographer: The Role of Cook's Journals in the Formation of the Ethnographic Genre" Lethbridge Undergraduate Research Journal 3(1). Retreived from https://lurj.org/issues/volume-3-number-1/cook (accessed 20 December 2017).

Lipták, Dániel. (2017). “Hungarian Ethnomusicologist Oszkár Dincsér (1911-1977) as a Pioneer of Musical Anthropology." A National Master in International Context. International Musicological Conference on the 50th anniversary of Zoltán Kodály's Death. [Programm Abstracts], Biographies of Speakers. Budapest: HAC.

McLean, Mervyn. (2006). Pioneers of Ethnomusicology. Coral Springs: Llumina Press.

Meier, John. (1906). Kunstlieder im Volksmunde. Materialien und Untersuchungen. (Art Songs in the Mouths of the Folk. Materials and Investigations) Halle: Max Niemeyer.

Morgenstern, Ulrich. (2010). “'Musicae subtilioris ignari sunt' - 'einen beinahe auch liebreicheren Ton'. The Western Reception of Russian Folk Instrumental Music and Dance in the $16^{\text {th }}$ to the $18^{\text {th }}$ Centuries." Historical Sources and Source Criticism [ICTM Study Group on Historical Sources: Proceedings from the 17th International Conference in Stockholm, Sweden, May 21-25, 2008], Susanne Ziegler (ed.) (pp. 269288). Stockholm: Svenskt visarkiv.

Morgenstern, Ulrich. (2011). "Egalitarianism and Elitism in Ethnomusicology and Folk Music Scholarship" Systematic Musicology: Empirical and Theoretical Studies (Hamburger Jahrbuch für Musikwissenschaft 28), Ed. Albrecht Schneider, Arne von Ruschkowski: pp. 249-282.

Morgenstern, Ulrich. (2015). “Folk Music Research in Austria and Germany. Notes on Terminology, Interdisciplinarity and the Early History of Volksmusikforschung and 
Vergleichende Musikwissenschaft." Musicologica Austriaca - Journal for Austrian Music Studies. Retrieved from http://www.musau.org/parts/neue-articlepage/view/17 (accessed 22 December 2017).

Morgenstern, Ulrich. (2017). "Volksmusik im europäischen Diskurs zwischen. Wissenschaft, Ideologie und Aufführungspraxis. Eine Rückschau." (Folk Music in the European Discourse between Scholarship, Ideology and Performance Practice) Positionen zur Rolle alpiner Musiktraditionen in einer globalisierten Welt, ed. Florian Wimmer: pp. 17-39. Graz.

Mueller, Adeline. (2012) "An Alternative History of the Volkslied, 1791-1807." AMS/SEM/SMT Joint Meeting. http://www.ams-net.org/neworleans/handouts/423_Mueller.pdf, 25 (accessed 12 December 2017).

Myers, Helen. (1992). "Ethnomusicology.” In Ethnomusicology: An Introduction, ed. Helen Myers: 3-18. New York: Norton.

Nebrig, Alexander. (2014) “Die Welt als Lied. Der globale Anspruch von Herders Volksliedern." (The World as Song. The global Claim of Herder's Folk songs) In Figuren des Globalen. Weltbezug und Welterzeugung in Literatur, Kunst und Medien, eds. Linda Simonis and Christian Moser, 315-26. Göttingen: V\&R unipress GmbH.

Nettl, Bruno. (2005). The Study of Ethnomusicology: Thirty-one Issues and Concepts. Urbana: University of Illinois Press.

Nettl, Bruno. (2010). Nettl's Elephant. On the History of Ethnomusicology. Urbana: University of Illinois Press.

Nettl, Bruno. (2015). The Study of Ethnomusicology: Thirty-Three Discussions. Urbana: University of Illinois Press. [Original work published 1983]

Newell, William Wells. (1884). Games and Songs of American Children. New York, Harper \& Brothers.

Nisbet, Hugh Barr. (1985). German Aesthetic and Literary Criticism: Winckelmann, Lessing, Hamann, Herder, Schiller and Goethe. Cambridge: Cambridge University Press. 
Noyes, John K. (2015). Herder: Aesthetics against Imperialism. Toronto: University of Toronto Press.

Pettan, Svanibor. (2001). “Encounter with 'The Others from Within': The Case of Gypsy Musicians in Former Yugoslavia” The World of Music. 43(2,3): 119-137.

Porter, James. (1991). "Muddying the Crystal Spring: From Idealism and Realism to Marxism in the Study of English and American Folk Song." Comparative Musicology and Anthropology of Music. Ed. Nettl, Bruno and Bohlman, Philip: pp. 113-130. Chicago: The University of Chicago Press.

Printz, Wolfgang Caspar. (1690). Historische Beschreibung der Edelen Sing- und Kling-Kunst. (A Historical Description of the noble Art of Singing and Playing) Dresden: Mieth.

Quigley, Colin. (1995). Music from the Heart: Compositions of a Folk Fiddler. Athens and Georgia: The University of Georgia Press.

Reyes, Adelaida. (2007a). "Introduction." Cultural Diversity in the Urban Area: Explorations in Urban Ethnomusicology, Eds. Ursula Hemetek and Adelaida Reyes: pp. 9-14. Wien: Institut für Volksmusikforschung und Ethomusikologie.

Reyes, Adelaida. (2007b). "Urban Ethnomusicology Revisited. An Assessment of its Role in the Development of its Parent Discipline." Cultural Diversity in the Urban Area $[\ldots]: 15-26$.

Richter, Pál (ed. 2012). Musical Traditions: Discovery, Inquiry, Interpretation, and Application. Budapest: HAS Research Centre for the Humanities.

Ringer, Alexander L. (1991). “One World or None? Untimely Reflections on a Timely Musicological Question" Comparative Musicology and Anthropology of Music. Ed. Nettl, Bruno and Bohlman Philip: pp. 187-200. Chicago: The University of Chicago Press.

Rowbotham, John Frederick. (1885). A History of Music. Vol. I, London: Trübner.

Said, Edward. (1978). Orientalism. New York: Pantheon. 
Schneider, Albrecht. (1976). Musikwissenschaft und Kulturkreislehre. Zur Methodik und Geschichte der Vergleichenden Musikwissenschaft. (Musicology and the Theory of Culture Circles. Towards Method and History of Comparative Musicology) Bonn: Orpheus.

Schneider, Albrecht. (1984). Analogie und Rekonstruktion. Studien zur Methodologie der Musikgeschichtsschreibung und zur Frühgeschichte der Musik. (Analogy and Reconstruction. Studies on the Methodology of Music Historiography and Early History of Music) Band 1. Bonn: Orpheus.

Schneider, Albrecht. (1997). Tonhöhe, Skala, Klang: akustische, tonometrische und psychoakustische Studien auf vergleichender Grundlage. (Pitch, Scale, Sound: Studies in Acoustics, Tonometry and Psychoacoustics on Comparative Basis) Bonn: Orpheus.

Stafford, William C. (1830). History of Music. Edinburgh: Constable and Co.

Stählin, Jacob von. (1770) "Nachrichten von der Musik in Rußland" (News oft he Music in Russia) In M. Johann Joseph Haigold's Beylagen zum Neuveränderten Rußland: Zweiter Theil. pp. 37-192. Riga: J. F. Hartknoch.

Stockmann, Doris. (1985). "Musica vulgaris im französischen Hochmittelalter: Johannes de Grocheo in neuer Sicht." (Musica vulgaris in High Medieval France. J. d. G. in a New Perspectice) Musikethnologische Sammelbände 7. Historische Volksmusikforschung, ed. Wolfgang Suppan: pp. 163-80. Graz. Akademische Druck- u. Verlagsanstalt.

Thoms, William John. (1858). Early English Prose Romances: with Bibliographical and Historical Introductions, Volume 1. London: Nattali and Bond.

Uhland, Ludwig. (1845). Alte hoch- und niederdeutsche Volkslieder: Liedersammlung mit Abhandlung und Anmerkungen. (Old High and Low German Folk Songs. A Song Collection with Studies and Comments) Stuttgart: Cotta.

Wiora, Walter. (1957). Europäische Volksmusik und abendländische Tonkunst. (European Folk Music and Western Art of Music) Kassel: Hinnenthal. 
Zemtsovsky, Izaly. (2012). "Ethnic Hearing in the Sociocultural Margins: Toward the Identity of Homo Musicans Polyethnoaudiens" Garment and Core: Jews and their Musical Experiences, Ed. Eytan Avitsur and Marina Ritzarev, Edwin Seroussi: pp. 1330. Tel Aviv: Bar-Ilan University Press.

Zon, Bennett. (2006). “From 'Incomprehensibility' to 'Meaning': Transcription and Representation of Non-Western Music in Nineteenth-Century British Musicology and Ethnomusicology." Europe, Empire, and Spectacle in Nineteenth-Century British Music, Eds. Rachel Cowgill and Julian Rushton: pp. 185-199. Aldershot: Ashgate.

Zon, Bennett. (2007). Representing Non-Western Music in Nineteenth-century Britain. Rochester, NY: University Rochester Press. 